\title{
Formulation and Evaluation of Fast Dissolving Tablets of Ondansetron by Solid Dispersion in Superdisintegrants
}

\author{
Rajnikant M. Suthar ${ }^{1}$, Narendra P. Chotai ${ }^{* 1}$ and Digesh D. Shah ${ }^{2}$ \\ ${ }^{1}$ A. R. College of Pharmacy and G. H. Patel Institute of Pharmacy, PO Box No.19 Motabazar, Vallabh Vidyanagar-388120, \\ Anand, Gujarat, India. \\ ${ }^{2}$ Sanofi Aventis Pharmaceuticals Ltd. Ankleshwar, Gujarat, India.
}

\begin{abstract}
Ondansetron Hydrochloride (OSH) is a sparingly water-soluble drug. The aim of the present investigation was to prepare solid dispersion (SD) of OSH using superdisintegrants as carrier and formulate it as fast dissolving tablets (FDTs) with an objective to improve solubility and enhance dissolution of drug. SD of drug using superdisintegrants like croscarmellose sodium (CCS), crospovidone (CP), sodium starch glycolate (SSG), and low substituted hydroxy propyl cellulose (L-HPC) respectively as carriers was prepared by solvent evaporation method. The prepared SD formulations were characterized by equilibrium solubility, fourier transform infrared spectroscopy (FTIR), X-ray powder diffraction (XRPD), differential scanning calorimetry (DSC) and dissolution study. FTIR spectra revealed no chemical interaction between the drug and superdisintegrants. XRPD and DSC data indicated that OSH was in the amorphous form, which explains the better dissolution rate of the drug from its solid dispersions. Various batches of FDTs (F1-F10) were prepared using selected SD formulation of drug and carrier (1:3 ratio) and evaluated for various physical parameters and drug release study. The batch containing SD formulation in CP (F3) showed fastest disintegration (3.22s), least wetting time (10.5s) and higher dissolution (97.98\% drug release in $30 \mathrm{~min}$ ). In conclusion, FDTs of OSH prepared using SD with CP seems to be promising formulations.
\end{abstract}

Keywords: OSH, Superdisintegrants, Solid dispersions, Fast dissolving tablets.

\section{INTRODUCTION}

OSH is an effective and well-tolerated antiemetic, which is used for the prevention of both chemotherapy and radiotherapyinduced emesis and nausea. It is sparingly soluble in water and well absorbed from the gastrointestinal tract and undergoes some first-pass metabolism. ${ }^{1}$ Mean bioavailability in healthy subjects, following oral administration of a single 8-mg tablet, is approximately $56 \%$.

In case of poorly water soluble drugs, dissolution is the rate-limiting step in the process of drug absorption. Various techniques, such as self emulsifying drug delivery system ${ }^{2}$, solid dispersions ${ }^{3}$, crystal engineering ${ }^{4}$, complexation ${ }^{5}$, freeze drying $^{6}$, orodispersible tablet ${ }^{7}$, reduction of particle size, supercritical fluid methods ${ }^{8}$, solid dispersion granules using hot melt granulation technique ${ }^{9}$ were reported previously.

Tablet is the most popular among all dosage forms existing today because of its convenience of self administration, compactness and easy manufacturing; however hand tremors, dysphagia in case of geriatric patients, the underdeveloped muscular and nervous systems in young individuals and in case of uncooperative patients, the problem of swallowing is common phenomenon which leads to poor patient compliance. $^{10}$

To overcome these drawbacks, FDTs has emerged as an alternative oral dosage forms. The basic approach used in development
DOI: $10.5530 /$ /jper.47.3.8

Address for correspondence Narendra Chotai A. R. College of Pharmacy and G. H. Patel Institute of Pharmacy, PO Box No.19 Motabazar, Vallabh Vidyanagar-388120,

Anand, Gujarat, India. E-Mail: pharmacist_chotai2002@ yahoo.co.in

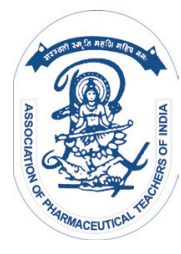

www.ijper.org 
of FDTs is the use of superdisintegrants which provide instantaneous disintegration of tablet after placing on tongue, thereby releasing the drug in saliva. ${ }^{11-13}$

A "Superdisintegrants" is an excipient, which is added to tablet to aid in the breakup of the compacted mass, when put into a fluid environment. This is especially important for immediate release product where rapid release of the product is required. These newer substances are more effective at lower concentrations with greater disintegrating efficiency and mechanical strength. The use of superdisintegrants is the basic approach in the development of fast disintegrating tablets (FDTs). Superdisintegrants plays a major role in the dissolution and disintegration of the tablets. ${ }^{14}$

Another approach used in developing such tablets is maximizing pore structure of the tablets by incorporating subliming agent. Sublimation technique was adopted after addition of a subliming agent like camphor to increase porosity of the tablets. It is likely that a porous hydrophilic matrix may easily pick up the disintegrating medium and break quickly. Therefore, it was decided to adopt the direct compression and sublimation techniques in the present investigation. ${ }^{15,16}$

The aim of the present study was to prepare SD of OSH using superdisintegrants (CCS, CP, SSG, and L-HPC) as carrier by solvent evaporation method with an objective to improve solubility and enhance dissolution of drug. Water dispersible superdisintegrants, a new class of tablet excipients were evaluated as carriers for enhancing the dissolution rate and bioavailability of drug was reported. ${ }^{17-19}$

In order to characterize the prepared dispersions, solubility study, FTIR, DSC, XRPD, as well as dissolution study were performed. FDTs were formulated from SD by direct compression and sublimation method using selected SD formulations and evaluated for various physical parameters and in vitro drug release study.

The mechanisms by which drug dissolution enhancement occurs by superdisinegrants are numerous and not yet well understood; however, factors such as improved wettability, increased effective surface area, loss of drug crystallinity, and solubilization effects associated with the carrier are probably responsible for their effect. ${ }^{20}$

\section{MATERIALS AND METHODS}

\section{Materials}

OSH, mannitol, aspartame, CCS, CP, SSG, and L-HPC were received from Zydus Cadila Ltd., Ahmedabad. Microcrystalline cellulose PH-101 was received from Relax Pharmaceuticals Ltd., Baroda. Camphor, magnesium stearate and talc were supplied from Molychem Ltd., Samir Tech Chem Pvt. Ltd., and Allied Chemical Corporation Ltd., Baroda respectively. Other reagents and chemicals used were of analytical reagent grade.

\section{Preparation of solid dispersion and physical mixture}

SD of OSH:superdisintegrants (CP, L-HPC, CCS, and SSG) were prepared by solvent evaporation method in the ratio of 1:1, 1:2, and 1:3. OSH and carrier (CP, L-HPC, CCS and SSG) were weighed accurately and triturated in a mortar and pestle for $5 \mathrm{~min}$. The physical mixture was then dissolved in alcohol with constant stirring. The solvent was evaporated at $60^{\circ} \mathrm{C}$ for $4 \mathrm{~h}$ in vaccum oven (Cintex Industries, India). The co-precipitate obtained was powdered in a mortar and passed through a 80 mesh sieve and stored in a desiccator at room temperature for $24 \mathrm{~h}$. Physical mixtures (PM) were also prepared in the ratio of $1: 1,1: 2$, and 1:3 of OSH:Carrier and mixed well in a mortar and sifted through 80 mesh. $^{20}$

\section{Characterization of solid dispersion}

\section{Equilibrium solubility studies ${ }^{21}$}

The equilibrium solubility of pure OSH powder, prepared $\mathrm{SD}$ and PM was determined. The known excess amount (approximately $10 \mathrm{mg}$ ) of $\mathrm{OSH}$ and SD and PM (eqiuvalent to $10 \mathrm{mg}$ of $\mathrm{OSH}$ ) was placed in a sealed glass container containing $20 \mathrm{~mL}$ of distilled water. Samples were stirred at $37 \pm 0.5^{\circ} \mathrm{C}$ on a magnetic stirrer for $48 \mathrm{~h}$. After attainment of equilibrium, the samples were then filtered through a 0.45 micron filter. The filtrate was diluted and assayed spectrophotometrically (UV-1601, Shimadzu Corporation, Japan) for OSH content at $310 \mathrm{~nm}$. All solubility measurements were performed in triplicate.

\section{Fourier transform infrared spectroscopy}

FTIR spectra of the pure drug, excipients and prepared SD were obtained on a Perkin-Elmer 1600 FTIR spectrometer (Perkin elmer, spectrum GX FTIR system USA). Samples were prepared in $\mathrm{KBr}$ disks (2 mg sample in $200 \mathrm{mg} \mathrm{KBr}$ ). The scanning range was 400 to $4000 \mathrm{~cm}^{-1}$ and the resolution was $1 \mathrm{~cm}^{-1}$.

\section{$X$-ray powder diffraction}

XRPD patterns of pure drug, superdisintegrants and prepared SD were taken using a powder diffractometer (X'pert, MP. Philips) with $\mathrm{CuK} \alpha$ radiation. Powedered samples were studied by placing a thin layer of powder in conventional cavity mounts.

\section{Differential scanning calorimetry}

The DSC thermograms of pure drug, superdisintegrants and solid dispersions were recorded on a DSC (Perkin elmer Instruments, Pyris-1 DSC, USA). The samples were 
weighed and heated in hermetically sealed aluminium pans over a temperature range of $50^{\circ} \mathrm{C}$ to $300^{\circ} \mathrm{C}$. The system was purged with nitrogen gas at a flow rate of $80 \mathrm{ml} / \mathrm{min}$.

\section{Dissolution studies}

The quantity of SD powder equivalent to $8 \mathrm{mg} \mathrm{OSH}$ was used for dissolution studies. Dissolution was performed in triplicate using the USP type II apparatus (Scientific USP Standards DA-60) in distilled water at $37 \pm 0.5^{\circ} \mathrm{C}$ at $50 \mathrm{rpm}$ and study was conducted for $30 \mathrm{~min}$. $5 \mathrm{~mL}$ sample was collected at 5,10,15 and 30 min time intervals and volume of dissolution fluid was adjusted to $500 \mathrm{~mL}$, by replacing each $5 \mathrm{~mL}$ aliquot withdrawn with $5 \mathrm{~mL}$ of distilled water. Samples withdrawn were filtered through whatmann filter paper ( 0.45 micron), suitably diluted and assayed for $\mathrm{OSH}$ by measuring absorbance at $310 \mathrm{~nm}$ using UV-Visible double beam spectrophotometer. ${ }^{22}$

\section{Preparation of fast dissolving tablets}

Ten batches of FDTs were prepared by direct compression (6 batches) and sublimation technique (4 batches) as per composition shown in Table 1. Mannitol, microcrystalline cellulose PH101, camphor (in case of sublimation technique) and aspartame were passed through 60 mesh before use. The drug as such, 1:3 SD or in 1:3 PM with CP and excipeints were blended together by tumbling for $10 \mathrm{~min}$. The blend was lubricated with $1 \%$ magnesium stearate and $2 \%$ talc. The resulting blend was directly compressed in to tablets using a rotary tablet machine. (RSB-4 mini press, Rimek, India). Compressed tablets containing camphor were subjected to the process of sublimation in vaccum oven at $60^{\circ} \mathrm{C}$ for $6 \mathrm{~h}$.

\section{Evaluation of tablets ${ }^{23}$}

\section{The Weight variation}

Twenty tablets were weighed individually and the average weight was determined. The percentage deviation was calculated and evaluated for weight variation.

\section{Thickness}

The thickness of five tablets was measured using a Vernier caliper.

\section{Hardness}

Tablet hardness (tablet crushing strength), the force required for breaking a tablet in a diametric compression of five tablets was measured using monsanto hardness tester (Dolphin, Mumbai).

\section{Friability}

Pre-weighed sample of ten tablets was placed in the Roche friabilator (Erection and Instrumentation Engineers, Ahmedabad) and were subjected to 100 revolutions. Tablets were dedusted using a soft muslin cloth and reweighed. The percentage friability is calculated.

\section{In vitro disintegration time}

The disintegration time of five tablets was measured using modified disintegration method. For this purpose, a petridish $(10 \mathrm{~cm}$ diameter $)$ was filled with $10 \mathrm{~mL}$ distilled water. The tablet was carefully put in the center of the petridish and the time for the tablet to disintegrate completely in to fine particles was noted as disintegration time. ${ }^{24}$

\section{Wetting time}

The wetting time of five tablets was measured by placing 5 circular tissue papers to simulate the tongue conditions in a petridish with a $10 \mathrm{~cm}$ diameter. $10 \mathrm{~mL}$ of water containing methylene blue, a water-soluble dye, was added to the petri dish. A tablet was carefully placed on the surface of the tissue paper. The time required for water to reach the upper surface of the tablets was noted as the wetting time. ${ }^{25}$

\section{Drug content}

Five tablets were crushed in mortar and powder equivalent to $8 \mathrm{mg}$ OSH was dissolved in sufficient quantity of distilled water and make up volume in $100 \mathrm{~mL}$ volumetric

\begin{tabular}{|c|c|c|c|c|c|c|c|c|c|c|}
\hline \multirow{2}{*}{ Ingredient } & \multirow{2}{*}{$\begin{array}{l}\text { F1^ } \\
\text { OSH }\end{array}$} & $\mathbf{F 2}$ & F3 & F4 & F5 & F6 & F7 & F8 & F9 & \multirow{2}{*}{$\frac{\mathrm{F} 10^{*}}{(\mathrm{OSH}+\mathrm{CP})}$} \\
\hline & & \multicolumn{2}{|c|}{$(\mathrm{OSH}+\mathrm{CP})$} & \multicolumn{2}{|c|}{ (OSH + L-HPC) } & \multicolumn{2}{|c|}{ (OSH + CCS) } & \multicolumn{2}{|c|}{ (OSH + SSG) } & \\
\hline $\mathrm{OSH}$ & $8 \mathrm{mg}$ & - & - & - & - & - & - & - & - & \\
\hline $1: 3 \mathrm{OSH}$-superdisintegrant SD & - & $32 \mathrm{mg}$ & $32 \mathrm{mg}$ & $32 \mathrm{mg}$ & $32 \mathrm{mg}$ & $32 \mathrm{mg}$ & $32 \mathrm{mg}$ & $32 \mathrm{mg}$ & $32 \mathrm{mg}$ & $32 \mathrm{mg}$ \\
\hline Microcrystalline Cellulose $\mathrm{PH}-101$ & $30 \mathrm{mg}$ & $30 \mathrm{mg}$ & $30 \mathrm{mg}$ & $30 \mathrm{mg}$ & $30 \mathrm{mg}$ & $30 \mathrm{mg}$ & $30 \mathrm{mg}$ & $30 \mathrm{mg}$ & $30 \mathrm{mg}$ & $30 \mathrm{mg}$ \\
\hline Mannitol & $100 \mathrm{mg}$ & $76 \mathrm{mg}$ & $76 \mathrm{mg}$ & $76 \mathrm{mg}$ & $76 \mathrm{mg}$ & $76 \mathrm{mg}$ & $76 \mathrm{mg}$ & $76 \mathrm{mg}$ & $76 \mathrm{mg}$ & $76 \mathrm{mg}$ \\
\hline Aspartame & $7.5 \mathrm{mg}$ & $7.5 \mathrm{mg}$ & $7.5 \mathrm{mg}$ & $7.5 \mathrm{mg}$ & $7.5 \mathrm{mg}$ & $7.5 \mathrm{mg}$ & $7.5 \mathrm{mg}$ & $7.5 \mathrm{mg}$ & $7.5 \mathrm{mg}$ & $7.5 \mathrm{mg}$ \\
\hline Magnesium Stearate & $1.5 \mathrm{mg}$ & $1.5 \mathrm{mg}$ & $1.5 \mathrm{mg}$ & $1.5 \mathrm{mg}$ & $1.5 \mathrm{mg}$ & $1.5 \mathrm{mg}$ & $1.5 \mathrm{mg}$ & $1.5 \mathrm{mg}$ & $1.5 \mathrm{mg}$ & $1.5 \mathrm{mg}$ \\
\hline Talc & $3 \mathrm{mg}$ & $3 \mathrm{mg}$ & $3 \mathrm{mg}$ & $3 \mathrm{mg}$ & $3 \mathrm{mg}$ & $3 \mathrm{mg}$ & $3 \mathrm{mg}$ & $3 \mathrm{mg}$ & $3 \mathrm{mg}$ & $3 \mathrm{mg}$ \\
\hline Camphor & - & - & $20 \mathrm{mg}$ & - & $20 \mathrm{mg}$ & - & $20 \mathrm{mg}$ & - & $20 \mathrm{mg}$ & - \\
\hline
\end{tabular}

*F10 batch contains 1:3 PM of OSH: $\mathrm{CP}_{i} \wedge^{\mathrm{F}} \mathrm{F}_{1}$ batch does not contain SD formulation. 
flask. The solution was filtered through whatmann filter paper (0.45 micron), suitably diluted with distilled water, and analyzed at $310 \mathrm{~nm}$, using a UV-Visible double beam spectrophotometer. Each sample was analyzed in triplicate.

\section{In vitro dissolution study of fast dissolving tablets}

USP type II apparatus was used for dissolution of FDTs. Three tablets from each batch were used to determine the dissolution of drug. The dissolution media was $500 \mathrm{~mL}$ distilled water, maintained at $37 \pm 0.5^{\circ} \mathrm{C}$ to permit the sink condition. ${ }^{26}$ The rotation speed is $50 \mathrm{rpm}$. Aliquots were withdrawn at 5, 10, 15 and 30 min time intervals and replenished immediately with same volume of fresh dissolution media. Aliquots were analyzed spectrophotometrically at $310 \mathrm{~nm}$, using UV-Visible double beam spectrophotometer. The release profile of promising batches which showed higher drug release was compared with marketed product of mouth dissolving tablets of $\mathrm{OSH}$.

\section{RESULTS AND DISCUSSION}

\section{Solubility measurement}

The equilibrium solubility data are shown in Table 2 . The solubility of $\mathrm{OSH}$ powder in distilled water at $37 \pm 0.5^{\circ} \mathrm{C}$ was $0.724 \mathrm{mg} / \mathrm{ml}$ whereas solubility of SD and PM in the range of $3.112-7.124 \mathrm{mg} / \mathrm{ml}$ and $1.960-4.316 \mathrm{mg} / \mathrm{ml}$ respectively. These findings suggest that SD had much more enhanced equilibrium solubility (5-10 folds) as compared to pure drug powder and physical mixtures

\begin{tabular}{|c|c|c|c|}
\hline \multirow{3}{*}{$\begin{array}{l}\text { Drug to } \\
\text { Carrier ratio }\end{array}$} & \multicolumn{3}{|c|}{ Solubility $(\mathrm{mg} / \mathrm{ml}) \dagger$} \\
\hline & \multirow{2}{*}{$\begin{array}{l}\text { Drug with or } \\
\text { without carrier }\end{array}$} & \multicolumn{2}{|c|}{ Type of formulation } \\
\hline & & SD & PM \\
\hline $1: 0$ & $\mathrm{OSH}$ & \multicolumn{2}{|c|}{$0.724 \pm 0.529$} \\
\hline \multirow{4}{*}{$1: 1$} & $\mathrm{OSH}+\mathrm{CP}$ & $4.012 \pm 0.812$ & $2.826 \pm 0.314$ \\
\hline & $\mathrm{OSH}+\mathrm{L}-\mathrm{HPC}$ & $3.912 \pm 0.556$ & $2.584 \pm 0.286$ \\
\hline & $\mathrm{OSH}+\mathrm{CCG}$ & $3.112 \pm 0.534$ & $1.960 \pm 0.413$ \\
\hline & $\mathrm{OSH}+\mathrm{SSG}$ & $3.564 \pm 0.242$ & $2.126 \pm 0.297$ \\
\hline \multirow{4}{*}{$1: 2$} & $\mathrm{OSH}+\mathrm{CP}$ & $5.843 \pm 0.926$ & $3.424 \pm 0.527$ \\
\hline & $\mathrm{OSH}+\mathrm{L}-\mathrm{HPC}$ & $5.214 \pm 0.801$ & $3.362 \pm 0.713$ \\
\hline & $\mathrm{OSH}+\mathrm{CCG}$ & $4.384 \pm 0.612$ & $2.728 \pm 0.628$ \\
\hline & $\mathrm{OSH}+\mathrm{SSG}$ & $4.957 \pm 0.756$ & $3.287 \pm 0.345$ \\
\hline \multirow{4}{*}{$1: 3$} & $\mathrm{OSH}+\mathrm{CP}$ & $7.127 \pm 0.768$ & $4.316 \pm 0.387$ \\
\hline & $\mathrm{OSH}+\mathrm{L}-\mathrm{HPC}$ & $6.646 \pm 0.996$ & $4.125 \pm 0.811$ \\
\hline & $\mathrm{OSH}+\mathrm{CCG}$ & $5.815 \pm 0.769$ & $3.816 \pm 0.765$ \\
\hline & $\mathrm{OSH}+\mathrm{SSG}$ & $6.185 \pm 0.212$ & $4.016 \pm 0.714$ \\
\hline
\end{tabular}

$\mathrm{SD}$, solid dispersion; PM, physical mixture.

+Mean $\pm \mathrm{SD}$; standard deviation $\mathrm{n}=3$.
(2-6 folds). The solubility of drug was increased by increasing the proportion of superdisintegrants from 1:1 to $1: 3$ in SD and PM. Therefore 1:3 SD formulations were selected for preparation of FDTs. It may be noted that the equilibrium solubility of SD was increased which may be probably due to decrease in crystallinity or conversion from crystalline to amorphous form. ${ }^{27}$

\section{Fourier transform infrared spectroscopy}

The I.R. spectroscopy of OSH powder, superdisintegrants and some selected samples of SD (1:3) was carried out in order to get evidence on the possible interaction of the drug with the superdisintegrants and solid state characterization of SD (Fig. 1). Pure OSH displays a peak characteristic of the N-H bending vibration at $1638.1 \mathrm{~cm}^{-1}$ and a band with main strong peak at $1280.62 \mathrm{~cm}^{-1}$ and $760.1 \mathrm{~cm}^{-1}$ indicative of C-N stretching and ortho-substitution phenyl $\mathrm{C}-\mathrm{H}$ bending resprectively. It is evident that peaks of different functional groups of OSH in various solid dispersions were not much deviated from peaks of pure drug. In other words IR spectra of SD were identical to those of the corresponding pure drug and superdisintegrants. Consequently, the FTIR SD seemed to be only a combination of drug and superdisintegrant spectra. This result suggested that there was no interaction between drug and excipient in their combinations.

\section{X-ray powder diffraction}

The diffraction pattern of pure OSH, superdisintegrants and selected SD (1:3) is shown in Figure 2. The powder diffraction patterns of pure OSH exhibited characteristic high-intensity diffraction peaks. The powdered superdisintegrant was amorphous where it had only few peaks with very weak intensities. The crystalline structure of OSH was destroyed in SD which was evident from decrease in number and intensity of peaks. In other words these findings suggest that the OSH crystals might have converted to amorphous form in $\mathrm{SD}$ which was considered to be mainly responsible for the dissolution enhancement.

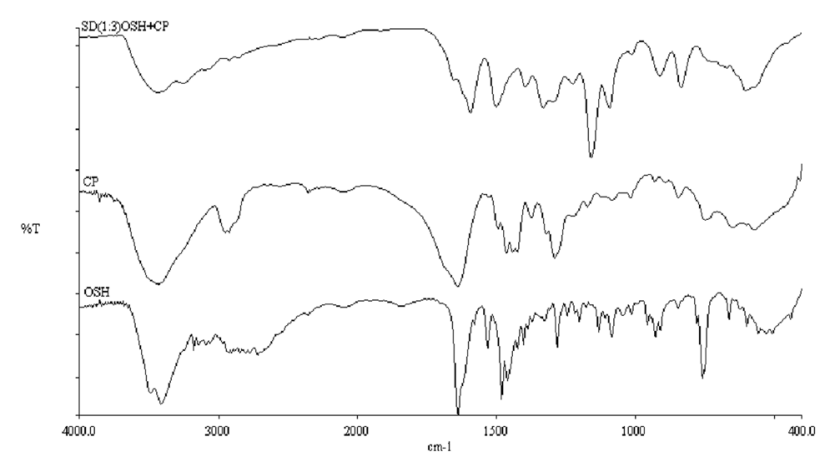

Figure 1: FTIR spectra of pure $\mathrm{OSH}, \mathrm{CP}$ and $1: 3 \mathrm{SD} \mathrm{OSH}: \mathrm{CP}$. 


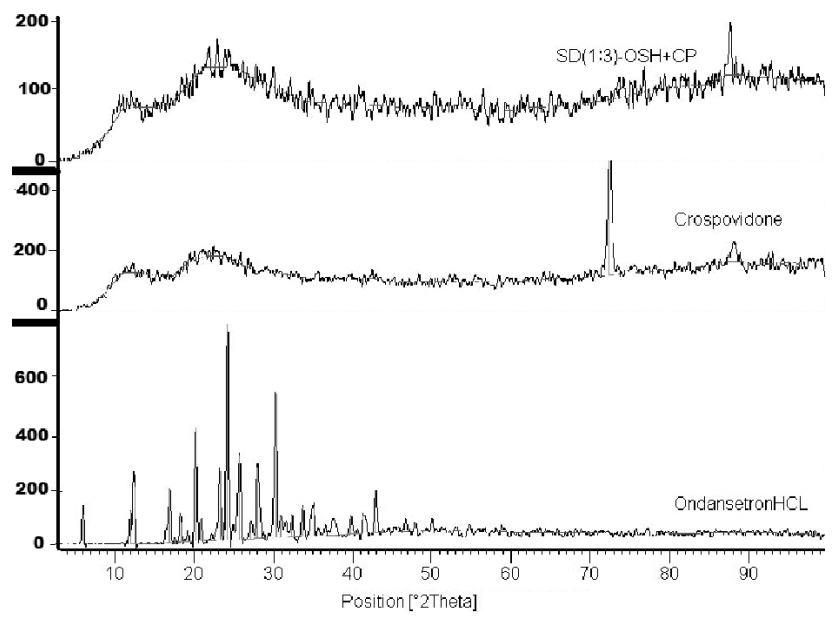

Figure 2: XRD patterns of pure $\mathrm{OSH}, \mathrm{CP}$ and 1:3 SD of $\mathrm{OSH}: \mathrm{CP}$.

\section{Differential scanning calorimetry}

The DSC thermogram of OSH exhibited an endothermal peak at $186.707^{\circ} \mathrm{C}$ corresponding to its melting point. SD of $\mathrm{OSH}$ in various superdisintegrants also gave a melting peak but at slightly lower temperature in the range of $174-185^{\circ} \mathrm{C}$ (Fig. 3) with decrease in intensity of peak as compared to pure OSH which indicate the weak endothermic reaction between OSH and superdisintegrants. The decrease in intensity and broadening of peak indicate amorphous nature of drug which ultimately leads to dissolution enhancement.

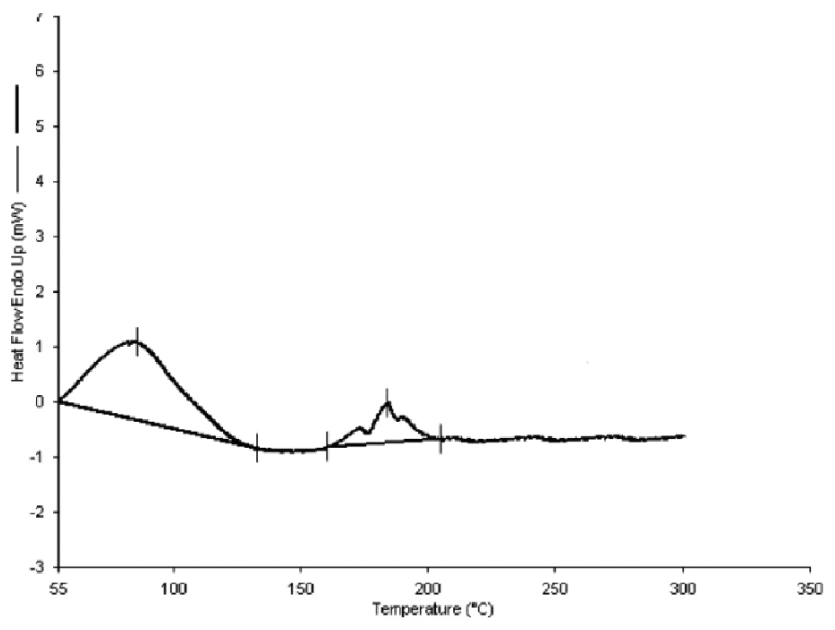

Figure 3: DSC thermogram of 1:3 SD of OSH: CP.

\section{Dissolution study}

The results of dissolution studies of pure drug, different SD and PM are shown in Table 3. It can be seen from the results that the percentage drug release from SD was $98 \%$ compared to only $30 \%$ for the pure drug and $74 \%$ for PM. It is evident from the results that solid dispersions exhibited about 3.5 fold increased dissolution compared to that of pure drug. The dissolution rate was increased by increasing the proportion of superdisintegrants from 1:1 to 1:3. The order for the superdisintegrants to enhance the dissolution rate could be

\section{Table 3: Cumulative Percentage OSH Released from Solid Dispersions and Physical Mixtures}

\begin{tabular}{|c|c|c|c|c|c|}
\hline \multirow{2}{*}{ Formulation } & \multirow{2}{*}{ Ratio } & \multicolumn{4}{|c|}{ Time^$^{\wedge}(\mathrm{min})$} \\
\hline & & 5 & 10 & 15 & 30 \\
\hline Drug (OSH) & $1: 0$ & $17.96 \pm 0.79$ & $21.20 \pm 0.109$ & $23.80 \pm 0.183$ & $31.25 \pm 0.424$ \\
\hline \multirow{3}{*}{$\mathrm{SD}(\mathrm{OSH}+\mathrm{CP})$} & $1: 1$ & $74.07 \pm 0.202$ & $77.23 \pm 0.112$ & $80.89 \pm 0.134$ & $85.51 \pm 0.097$ \\
\hline & $1: 2$ & $78.30 \pm 0.115$ & $83.34 \pm 0.042$ & $85.58 \pm 0.166$ & $91.31 \pm 0.053$ \\
\hline & $1: 3$ & $82.23 \pm 0.203$ & $86.44 \pm 0.046$ & $90.37 \pm 0.203$ & $97.11 \pm 0.126$ \\
\hline \multirow{3}{*}{$\mathrm{SD}(\mathrm{OSH}+\mathrm{L}-\mathrm{HPC})$} & $1: 1$ & $68.60 \pm 0.253$ & $71.86 \pm 0.07$ & $74.32 \pm 0.141$ & $79.34 \pm 0.139$ \\
\hline & $1: 2$ & $71.03 \pm 0.111$ & $74.53 \pm 0.038$ & $77.65 \pm 0.111$ & $84.54 \pm 1.136$ \\
\hline & $1: 3$ & $80.75 \pm 0.095$ & $82.34 \pm 0.056$ & $84.45 \pm 0.124$ & $90.91 \pm 0.175$ \\
\hline \multirow{3}{*}{$\mathrm{SD}(\mathrm{OSH}+\mathrm{CCS})$} & $1: 1$ & $60.71 \pm 0.097$ & $63.74 \pm 0.211$ & $67.05 \pm 0.428$ & $72.50 \pm 0.093$ \\
\hline & $1: 2$ & $64.87 \pm 0.094$ & $68.60 \pm 0.078$ & $70.19 \pm 0.083$ & $75.01 \pm 0.036$ \\
\hline & $1: 3$ & $72.40 \pm 0.097$ & $75.46 \pm 0.079$ & $78.57 \pm 0.084$ & $84.43 \pm 0.131$ \\
\hline \multirow{3}{*}{ SD (OSH + SSG) } & $1: 1$ & $63.60 \pm 0.245$ & $66.78 \pm 0.078$ & $69.56 \pm 0.134$ & $75.33 \pm 0.114$ \\
\hline & $1: 2$ & $67.03 \pm 0.056$ & $70.45 \pm 0.045$ & $74.56 \pm 0.134$ & $80.45 \pm 0.067$ \\
\hline & $1: 3$ & $78.67 \pm 0.086$ & $80.98 \pm 0.143$ & $82.56 \pm 0.098$ & $87.43 \pm 0.026$ \\
\hline $\mathrm{PM}(\mathrm{OSH}+\mathrm{CP})$ & \multirow{4}{*}{$1: 3$} & $40.92 \pm 0.204$ & $42.09 \pm 0.140$ & $45.51 \pm 0.180$ & $52.12 \pm 0.145$ \\
\hline PM (OSH + L-HPC) & & $38.22 \pm 0.102$ & $41.50 \pm 0.139$ & $46.33 \pm 0.090$ & $50.05 \pm 0.170$ \\
\hline $\mathrm{PM}(\mathrm{OSH}+\mathrm{CCS})$ & & $34.40 \pm 0.155$ & $40.20 \pm 0.146$ & $43.50 \pm 0.040$ & $46.69 \pm 0.098$ \\
\hline $\mathrm{PM}(\mathrm{OSH}+\mathrm{SSG})$ & & $37.13 \pm 0.247$ & $42.00 \pm 0.132$ & $44.41 \pm 0.221$ & $49.13 \pm 0.167$ \\
\hline
\end{tabular}

$\mathrm{OSH}, \mathrm{OSH} ; \mathrm{PM}$, physical mixture; $\mathrm{SD}$, solid dispersion.

$\wedge$ Mean $\pm \mathrm{SD}$; standard deviation $\mathrm{n}=3$. 


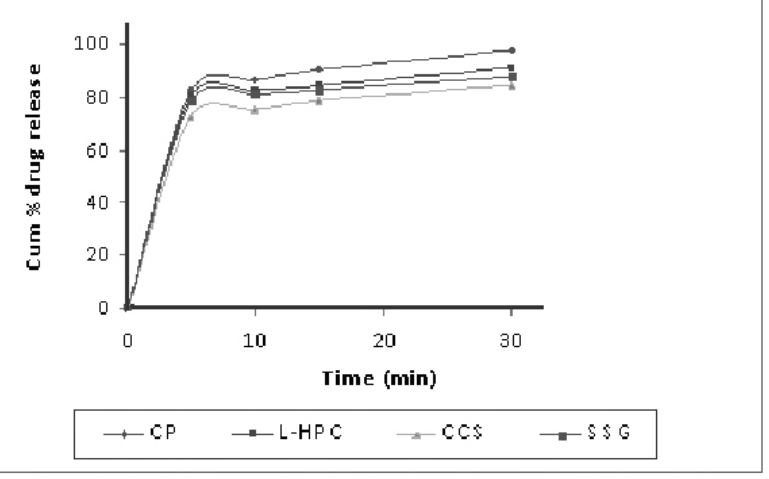

Figure 4: Comparative release profiles of pure OSH and SD formulations in a 1:3 ratio.

ranked as CP > L-HPC > SSG > CCS (Fig. 4). The mechanisms by which drug dissolution enhancement occurs from solid dispersions are numerous and not yet well understood; however, factors such as improved wettability, increased effective surface area, loss of drug crystallinity, and solubilization effects associated with the carrier are probably responsible for their effect. ${ }^{20}$

\section{Evaluation of fast dissolving tablets}

Tablets were prepared using direct compression and sublimation technique. Since the powder blends were free flowing, tablets were obtained of uniform weight due to uniform die fill, with acceptable weight variations as per pharmacopoeial specifications. The thickness of all batches was found in the range of $2.7-3.0 \mathrm{~mm}$ which indicates that tablet prepared were of uniform thickness (Table 4).The hardness of tablets was found between 2.5 to $4.3 \mathrm{Kg} / \mathrm{cm}^{2}$. Friability of the tablets was found below 1\% (Table 4) indicating good mechanical resistance of tablets. The drug content was found in the range of $95.14-98.52 \%$ (Table 4).

The disintegration time of all the formulations was found in the range of 3.22-8.79s (Table 4) which was within official requirements that are less than $30 \mathrm{~s}$. Wetting time was used as a parameter to correlate with disintegration time in oral cavity. This is an important criterion for understanding the capacity of disintegrants to swell in presence of little amount of water. Since the dissolution process of a tablet depends upon the wetting followed by disintegration of the tablet, the measurement of wetting time may be used as another confirmative test for evaluation of fast dissolving tablets. The wetting time of formulated tablets was found to be in the range of 10.5-22.59s (Table 4).

Dissolution results shows that more than $85 \%$ drug released after $30 \mathrm{~min}$ (Table 4) from all SD batches (F2-F9) as compared to batch F1 without SD (49\% release) and batch F10 containing PM (75\% release). It can be inferred from the results that batch containing $\mathrm{CP}$ (F2 and F3) exhibited higher dissolution rate $(97 \%$ release after $30 \mathrm{~min})$ as compared to that of batch containing CCS, L-HPC, and SSG (F4-F9). F3 batch was selected as promising formulation because of higher drug release, fastest disintegration time (3.22 s) and least wetting time (10.5 s).

\section{Comparison of release profile with marketed product}

The results revealed that promising batch exhibited comparable release profile with marketed mouth dissolving tablet (MMDT) as shown in Figure 5.

\begin{tabular}{|c|c|c|c|c|c|c|c|c|c|c|}
\hline Parameter & F1 & F2 & F3 & F4 & F5 & F6 & F7 & F8 & F9 & F10 \\
\hline $\begin{array}{l}\text { Average weight of } \\
\text { tablet }(\mathrm{mg})(n=20)\end{array}$ & $\begin{array}{l}152.05 \\
(1.069)\end{array}$ & $\begin{array}{l}149.77 \\
(2.362)\end{array}$ & $\begin{array}{l}150.84 \\
(1.676)\end{array}$ & $\begin{array}{l}148.18 \\
(2.003)\end{array}$ & $\begin{array}{l}151.18 \\
(1.783)\end{array}$ & $\begin{array}{l}149.92 \\
(1.039)\end{array}$ & $\begin{array}{l}152.45 \\
(1.112)\end{array}$ & $\begin{array}{l}145.56 \\
(2.897)\end{array}$ & $\begin{array}{l}151.67 \\
(2.675)\end{array}$ & $\begin{array}{l}153.75 \\
(2.456)\end{array}$ \\
\hline $\begin{array}{l}\text { Thickness } \\
(\mathrm{mm})(\mathrm{n}=5)\end{array}$ & $\begin{array}{c}3 \\
(0.110)\end{array}$ & $\begin{array}{c}2.9 \\
(0.055)\end{array}$ & $\begin{array}{c}2.8 \\
(0.114)\end{array}$ & $\begin{array}{c}2.8 \\
(0.122)\end{array}$ & $\begin{array}{c}2.9 \\
(0.217)\end{array}$ & $\begin{array}{c}2.9 \\
(0.045)\end{array}$ & $\begin{array}{c}2.8 \\
(0.084)\end{array}$ & $\begin{array}{c}2.7 \\
(0.164)\end{array}$ & $\begin{array}{c}2.7 \\
(0.259)\end{array}$ & $\begin{array}{c}3.0 \\
(0.110)\end{array}$ \\
\hline $\begin{array}{l}\text { Hardness } \\
\left(\mathrm{Kg} / \mathrm{cm}^{2}\right)(\mathrm{n}=5)\end{array}$ & $\begin{array}{c}3.0 \\
(0.134)\end{array}$ & $\begin{array}{c}4.3 \\
(0.023)\end{array}$ & $\begin{array}{c}4.3 \\
(0.037)\end{array}$ & $\begin{array}{c}3.5 \\
(0.103)\end{array}$ & $\begin{array}{c}2.8 \\
(0.094)\end{array}$ & $\begin{array}{c}3.3 \\
(0.114)\end{array}$ & $\begin{array}{c}3.0 \\
(0.045)\end{array}$ & $\begin{array}{c}3.2 \\
(0.065)\end{array}$ & $\begin{array}{c}2.5 \\
(0.051)\end{array}$ & $\begin{array}{c}4.1 \\
(0.141)\end{array}$ \\
\hline $\begin{array}{l}\text { Friability } \\
(\%)(n=3)\end{array}$ & $\begin{array}{c}0.421 \\
(0.0052)\end{array}$ & $\begin{array}{c}0.160 \\
(0.0029)\end{array}$ & $\begin{array}{c}0.189 \\
(0.0023)\end{array}$ & $\begin{array}{c}0.279 \\
(0.0074)\end{array}$ & $\begin{array}{c}1.003 \\
(0.0053)\end{array}$ & $\begin{array}{c}0.206 \\
(0.0022)\end{array}$ & $\begin{array}{c}0.457 \\
(0.0046)\end{array}$ & $\begin{array}{c}0.680 \\
(0.0058)\end{array}$ & $\begin{array}{c}2.313 \\
(0.0085)\end{array}$ & $\begin{array}{c}0.196 \\
(0.0012)\end{array}$ \\
\hline $\begin{array}{l}\text { Disintegration time } \\
(\mathrm{sec}) \quad(n=5)\end{array}$ & $\begin{array}{c}7.56 \\
(0.428)\end{array}$ & $\begin{array}{c}3.64 \\
(0.249)\end{array}$ & $\begin{array}{c}3.22 \\
(0.161)\end{array}$ & $\begin{array}{c}5.73 \\
(0.317)\end{array}$ & $\begin{array}{c}4.99 \\
(0.175)\end{array}$ & $\begin{array}{c}8.79 \\
(0.479)\end{array}$ & $\begin{array}{c}6.68 \\
(0.306)\end{array}$ & $\begin{array}{c}4.19 \\
(0.316)\end{array}$ & $\begin{array}{c}3.84 \\
(0.114)\end{array}$ & $\begin{array}{c}4.23 \\
(1.403)\end{array}$ \\
\hline $\begin{array}{l}\text { Wetting time } \\
(\mathrm{sec})(\mathrm{n}=5)\end{array}$ & $\begin{array}{c}14.12 \\
(1.473)\end{array}$ & $\begin{array}{c}12.68 \\
(0.675)\end{array}$ & $\begin{array}{c}10.50 \\
(1.347)\end{array}$ & $\begin{array}{c}17.12 \\
(0.812)\end{array}$ & $\begin{array}{c}14.49 \\
(0.504)\end{array}$ & $\begin{array}{l}32.80 \\
(0.933)\end{array}$ & $\begin{array}{l}22.59 \\
(1.241)\end{array}$ & $\begin{array}{c}16.29 \\
(0.541)\end{array}$ & $\begin{array}{c}11.45 \\
(0.845)\end{array}$ & $\begin{array}{c}13.22 \\
(1.364)\end{array}$ \\
\hline $\begin{array}{l}\% \text { Drug content } \\
(n=10)\end{array}$ & $\begin{array}{c}98.21 \\
(1.551)\end{array}$ & $\begin{array}{c}97.94 \\
(1.262)\end{array}$ & $\begin{array}{c}97.13 \\
(1.126)\end{array}$ & $\begin{array}{l}95.97 \\
(0.970)\end{array}$ & $\begin{array}{c}95.31 \\
(1.511)\end{array}$ & $\begin{array}{c}96.66 \\
(1.173)\end{array}$ & $\begin{array}{c}96.38 \\
(1.683)\end{array}$ & $\begin{array}{c}97.02 \\
(1.626)\end{array}$ & $\begin{array}{c}95.14 \\
(1.311)\end{array}$ & $\begin{array}{c}98.52 \\
(0.935)\end{array}$ \\
\hline $\begin{array}{l}\% \text { Drug release after } \\
30 \min (n=3)\end{array}$ & $\begin{array}{c}49.47 \\
(0.713)\end{array}$ & $\begin{array}{c}97.78 \\
(0.564)\end{array}$ & $\begin{array}{c}98.15 \\
(1.383)\end{array}$ & $\begin{array}{l}92.66 \\
(1.614)\end{array}$ & $\begin{array}{l}91.45 \\
(0.911)\end{array}$ & $\begin{array}{l}85.65 \\
(0.683)\end{array}$ & $\begin{array}{c}86.62 \\
(0.845)\end{array}$ & $\begin{array}{c}90.29 \\
(2.031)\end{array}$ & $\begin{array}{c}91.81 \\
(1.729)\end{array}$ & $\begin{array}{l}74.94 \\
(0.924)\end{array}$ \\
\hline
\end{tabular}

Value in the parenthesis indicates standard deviation. 


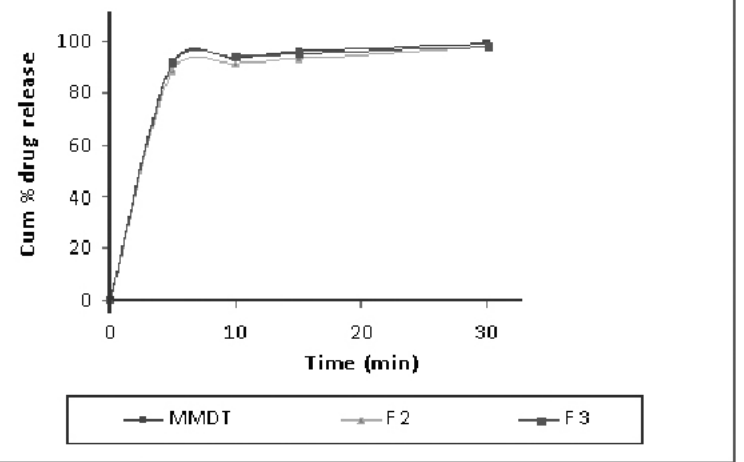

Figure 5: Comparative in vitro release profile of promising batch and marketed product.

\section{CONCLUSION}

In conclusion, fast dissolving tablets of Ondansetron prepared using solid dispersion with crospovidone seems to be promising formulations and further in vivo study may be carried out.

\section{ACKNOWLEDGEMENT}

The authors take this opportunity to thank Zydus Cadila Ltd., Ahmedabad, Relax Pharmaceuticals Ltd., Baroda for providing gratis sample of drug and excipients. The authors would like to thank Principal, A. R. College of Pharmacy and G. H. Patel Institute of Pharmacy, Vallabh Vidyanagar, Gujarat for providing facilities for conducting research work and Director, Sophisticated Instrumentation Center for Applied Research \& Testing (SICART), Vallabh Vidyanagar, Gujarat for providing facilities for sample analysis.

\section{REFERENCES}

1. Salem I, Lopez K, Galan A, Florey K. Profiles of Drug substances and Excipients $27^{\text {th }}$ Edition., California, USA Academic Press, 2000; pp. 304-16.

2. Dixit AR, Rajput SJ, Patel SG. Preparation and bioavailability assessment of SMEDDS containing valsartan, AAPS Pharm SciTech 2010; 11:314-21.

3. Raja RK, Abbulu K, Sudhakar M. Development, characterization and solubility study of solid dispersion of valsartan. J Chem Pharm Res 2011; 3:180-7.

4. Blagden N, Matas M, Gavan P, York P. Crystal engineering of active pharmaceutical ingredients to improve solubility and dissolution rates. Adv Drug Deliv Rev 2007; 59:617-30.
5. Jin X, Zhang Z, Sun E, Li S, Jia X. Statistically designed enzymatic hydrolysis of an icariin/b-cyclodextrin inclusion complex optimized for production of icaritin. Acta Pharma 2012; 2:83-9.

6. Cappello B, Maio DC, lervolino M, Miro A. Improvement of solubility and stability of valsartan by hydroxypropyl - bcyclodextrin. J Inclusion Phenomena Macrocyclic Chem 2005; 54:289-94.

7. Ibrahim HK, El-Setouhy DA. Valsartan orodispersible tablets: formulation, in vitro/in Vivo characterization. AAPS PharmSciTech 2010; 11:89-96.

8. Abbas KA, Mohamed A, Abdulamir AS, Abas HA. A review on supercritical fluid extraction as new analysis method. American J. Biochem Biotech 2008; 4:345-53.

9. Agnivesh R, Shrivastava, Bhalchandra, Ursekar, Chhanda J, Kapadia. Design, optimization, preparation and evaluation of dispersion granules of valsartan and formulation into tablets. Current Drug Del 2009; 6:28-37.

10. Habib W, Khankari R, Hontz J. Fast-dissolving drug delivery systems. Crit Re Ther Drug Carrier Systems 2000; 17:61-72.

11. Deepak S, Dinesh K, Mankaran S, Gurmeet S, Rathore MS. Fast disintegrating tablets: A new era in novel drug delivery system and new market opportunities. J Drug Deliv Ther 2012; 2(3):74-86.

12. Dobetti L. Fast-melting tablets: Developments and technologies. Pharm Tech 2001; 6:44-50.

13. Kuchekar BS, Atul Badhan C, Mahajan H S. Mouth dissolving tablets: A Novel drug delivery system. Pharma Times 2003; 35:7-9.

14. Allen LV, Wang B. Particulate support matrix for making a rapidly dissolving tablet. US Patent 55957611997.

15. Sastry SV, Nyshadham JR, Fix JA. Recent technological advances in oral drug delivery. Pharm Sci Tech Today 2000; 3:138-45.

16. Chang R, Guo X, Burnside B A, Couch R. Fast dissolving tablets. Pharm Tech 2000; 24:52-8.

17. Chaulang G, Patil K, Ghodke D, Khan S. Preparation and characterization of solid dispersion tablet of furosemide with crospovidone. Research J Pharm Tech 2008; 1(4):367-9.

18. Nagabhushanam MV. Formulation studies on solid dispersions of celecoxib in superdisintegrants alone and with PVP. Rasayan J Chem 2009; 2(3):691-8.

19. Nagabhushanam MV, Sudha Rani A. Dissolution enhancement of mefenamic acid using solid dispersions in crospovidone. Int J Pharm Pharm Sci 2011; 3(1):16-9.

20. Sammour OA, Hammad MA, Megrab NA, Zidan AS. Formulation and optimization of mouth dissolve tablets containing rofecoxib solid dispersion. AAPS PharmSciTech 2006; 7(2):345-52.

21. Chowdary KPR, Rao SK. Investigation of dissolution enhancement of itraconazole by solid dispersion in superdisintegrants. Drug Dev Ind Pharm 2000; 26(11):1207-11.

22. Valleri M, Mura P, Maestrelli F, Ballerini R. Development and evaluation of glyburide fast dissolving tablets using solid dispersion technique. Drug Dev Ind Pharm 2004; 30(5):525-34.

23. Liberman HA, Lachman L. Pharmaceutical Dosage Form: Tablets. $2^{\text {nd }}$ Edition Inc. New York Marcel Dekker, 2005; pp. 332-5.

24. Gohel M, Patel M, Amin A, Agrawal R, Dave R, Bariya N. Formulation design and optimization of mouth dissolve tablets of nimesulide using vaccum drying technique. AAPS PharmSciTech 2004; 5:212-8.

25. Shoukri R.A., Ahmed I.S., Shamma R.N. In vitro and in vivo evaluation of nimesulide lyophilized orally disintegrating tablets. Eur. J. Pharm. Sci. 2009; 73(1):162-71.

26. United States Pharmacopoeia, National Formulary, $30^{\text {th }}$ Edition. Rockville, United State Pharmacopeial Convection, 2007; pp. 2149-52.

27. Newa M, Bhandari KH, Kim JO et al. Enhancement of solubility, dissolution and bioavailability of ibuprofen in solid dispersion systems. Chem Pharm Bull 2008; 56(4):569-74. 